\title{
Phantom Housing: The Rise and Fall of Public Housing in North America
}

\author{
Benjamin Gianni \\ School of Architecture Carleton University, Ottawa, ON
}

\begin{abstract}
This paper examines the rise and fall of public housing in North America in order to explore the principle of sustainability. By extension, it addresses the concept of sustainability as it relates to the city. Urbanity is simultaneously the most and least sustainable form of development. While extremely sustainable from the point of view of density (economies of scale, efficient use of infrastructure, etc.), it is highly vulnerable to social, political and economic forces. Such forces can easily trump the environmental sustainability of any building or community.
\end{abstract}

The death and transfiguration of key portions of our public housing stock provides insights into this phenomenon - for which I will use Toronto's Regent Park as a case study. The redevelopment of this 69-acre parcel aims to transform a failed social vision into a model for sustainable community development.

Conference theme: Urban Design and Sustainable Elements

\begin{abstract}
INTRODUCTION
Pruit-Igoe was demolished to great aplomb in 1972. The detonation of Yamasaki's infamous housing project marked the beginning of the end of a social project and, arguably, of architectural modernism as a form of agency. The modernist architect-qua-reformer was discredited. By the mid '70s the building of large-scale public housing had all but ceased. It was determined that direct government involvement in the construction of housing (never not controversial in North America) was neither sustainable nor proven to have benefited the constituencies it was intended to benefit.
\end{abstract}

The bulk of public housing in North America was realized in the fifty-year period from the Depression through the 1970s. The traces of this activity are now being erased -- just as the neighborhoods it replaced were cleared to accommodate new approaches to housing and to city form. In the past decade, 125 different US housing authorities have received funding to demolish close to sixty thousand units of public housing ${ }^{\mathrm{i}}$. Among these are the usual suspects (i.e., the notorious "vertical ghettos" of the 1960s) as well as model, low-rise projects constructed during the Depression. Public housing is disappearing where you'd most expect it might - e.g., Chicago's decimated South Side ${ }^{i i}$ - but also in less likely places, namely the housing-starved neighborhoods of New Orleans. The demolition of the housing stock is less a question of its location, design or need than of the cost of life-cycle investment.

Given the focus of the conference, this paper explores the sustainability of public housing as a political, ideological, social, logistical and architectural undertaking. Key in the issue of sustainability is the ability to sustain public support. Given how controversial it was to build, it would be more controversial to invest in the lifecycle improvements required to upgrade the public housing stock to align with current standards. The alternative is to find innovative ways to replace it.

Although the dismantling of large-scale housing complexes in North America strongly suggests that public housing, in the manner it was realized, was not sustainable, there is a potential silver lining. Redevelopment presents an opportunity to apply sustainable design principles to the re-design of portions of our cities. Regent Park, a 69-acre public housing complex in downtown Toronto, is one example. Using Regent Park as a case study, this paper will consider what the history of public housing can teach us about the concept of sustainability as it applies to the city. 


\subsection{Public Housing}

Public housing represents a relatively modest percentage of the overall housing stock in North America; in Canada it accounts for only $4 \%$. For the purposes of housing policy the population is divided into five equal parts or quintiles. Targets project that the top three fifths (or 60\%) should live in units they own while the remaining two fifths $(40 \%)$ be accommodated in rental housing. It is expected that half of those who rent will pay market rates for their units while the remaining fifth, the lowest quintile, will qualify for rent subsidies ${ }^{\text {iii. }}$. Policies assume that no household should be forced to spend more than $25 \%$ of its income on housing.

Given that public housing comprises only $4 \%$ of the overall housing stock, only a fraction of the lowest quintile the approximately $20 \%$ of households that qualify for subsidies - can be accommodated in governmentsponsored housing. The majority of households receiving subsidies live in market (privately owned) rental housing ${ }^{\text {iv }}$.

As these figures demonstrate, direct government participation in the building of housing in North America is extremely low. This is in marked contrast with Europe where percentages of home ownership are significantly lower and where the bulk of the (rental) housing stock was built under the auspices of the government. This is not to say that governments in the US and Canada do not exercise control over the housing market, indeed they do. But housing in North America is controlled indirectly, through codes and regulations, legislation, lending policies, loan guarantees, and a wide range of tax incentives. Together these mechanisms are applied and adjusted to produce the quintile targets described above.

Government-sponsored housing is both a fairly recent and relatively short-lived phenomenon. Among the first examples in North America were the dwellings built for military personnel during WWI. By the mid 1970s direct government building had all but ceased in North America, although small amounts of third party, non-profit housing continue to be built.

Government-sponsored housing falls into two general categories: "public" housing (housing built and administered by the government) and "social" housing (undertaken by a third party with some form of government support). Social housing includes rental units built by non-profit church groups, beneficent organizations, trade unions, and citizen's groups. It also includes rental housing constructed by limited-dividend corporations (primarily insurance companies), much of which was built as market housing for the middle class during periods of housing shortages.

Public (as opposed to social) housing can be grouped into several categories:

- Wartime housing - built for military personnel and civilian workers involved in a war effort.

- The projects built for temporarily disadvantaged families from the late 1930 s to the mid ' 50 s. This housing was envisioned as a short-term way station, offering eligible families a "hand up not a hand out." It was also promoted as a means of injecting money into the economy, shoring up a struggling construction industry and addressing acute shortages in rental housing.

- Projects from the late 1950 s to the mid ' 70 s built to accommodate the (predominantly poor) populations displaced by urban renewal projects.

- Housing for the elderly. This represents the largest percentage of the public housing stock. It should be noted, however, that much of the housing built for seniors is social housing, i.e., built and administered by third-party groups.

While the large-scale, high density and predominantly urban public housing projects built in the 1950s and '60s represent a relatively small percentage of the overall public housing stock, they have come to embody the idea of public housing in North America. These projects are conspicuous due not only to the scale at which they were realized (vast numbers of city blocks were razed and reconfigured to make way for them) but because of the form they took. More often than not, these agglomerations were conceived as of "tower-in-the-park" enclaves that broke open congested urban fabric and lifted tenants out of squalor.

In both scale and design the "tower in the park" ensembles represented an aggressive departure from the traditional grain of the city and from the more modest, Depression-era projects that preceded them. The radical design approach was intended both as an antidote to and a homily on the inability of the city to accommodate the myriad changes wrought by industrialization. Moreover, these enclaves are of particular interest to architects in that they embody the modernist vision of the architect as social engineer and reformer. They represented a new alliance between the architect/planner and the state -- an experiment with a new form of agency.

\subsection{Regent Park}

Toronto's Regent Park is textbook example of the large, state-sponsored housing developments of the post WWII era. It comprises 69 acres on the east side of downtown Toronto and is home to 7500 people, all of whom 
rent at subsidized rates. Prior to its redevelopment in the late '40s the area was a warren of small streets and laneways connecting a mix of wood-frame dwellings and light industrial buildings. The neighborhood was targeted for slum clearance as early as 1931 and was in exceptionally poor condition by the end of WWII.

To the planners who envisioned a new approach to the design of cities, the dilapidated condition of urban neighborhood testified to the fact that the city, as produced by market forces, was not sustainable. A new era called for new design principles, a new scale of intervention, and a more direct role for government in the stewardship of cities. Private initiatives could only address deficits in a piecemeal fashion; moreover the market (or the failure thereof) had produced the problem in the first place.

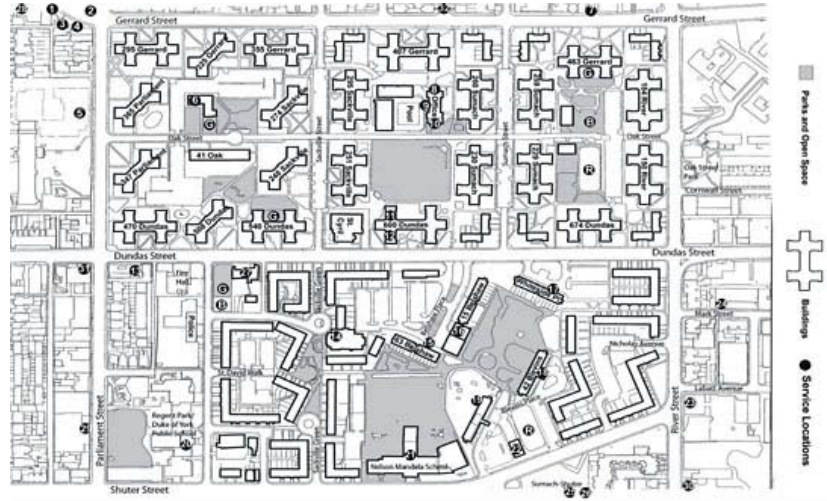

Figure 1: Plan of Regent Park, (pre-redevelopment), courtesy Toronto Community Housing Corporation

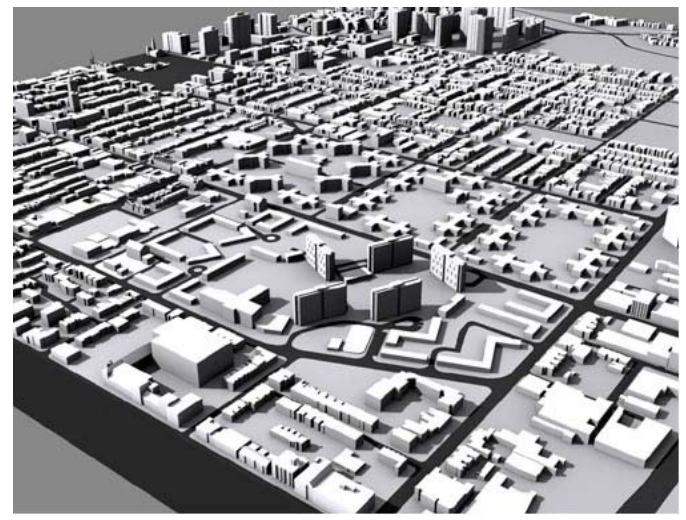

Figure 2: Model of Regent Park (pre-redevelopment), looking from southeast, courtesy author

Regent Park was constructed in two phases: the area north of Dundas St. (roughly 40 acres) in the late '40s and balance in the mid 1950s. Regent Park North was designed as an ensemble of three- and six-story walk-up buildings ("dumbbells" and "dog bones"), each with multiple, shared entrances and internal, double-loaded corridors. Ground level units had no direct access to the exterior, nor did many of the units include balconies or porches. The 6-story "dogbone" buildings were rotated at 45 degrees to the urban fabric to reinforce their separateness from adjacent neighborhoods. In all cases, buildings pulled away from and downplayed any relation to streets and access routes.

Pre-development, this 6-block area contained 765 dwelling units and several commercial properties, covering $36 \%$ of the area. Regent Park North was originally designed to accommodate 854 families and occupy only $15 \%$ of the land area. The goal of building higher was to free up land as "open space" for the community. Vacant land on the site meant that 248 new units could be constructed before any existing units were demolished." The new design of the neighborhood turned it inside out, consolidating all exterior spaces and eliminating private stewardship of land. Space became a community amenity under the aegis of the government.

Regent Park South (approximately 30 acres) was developed as a combination of townhouses and high-rise towers. While the inclusion of townhouses suggests a return to more time-honored urban housing types, the fourteen-story towers are resolutely modernist. These five towers are comprised of double-story units accessed though a skip-stop corridor system. And, as with Regent Park North, an effort was made to erase the preexisting street grid and float the buildings in a sea of parkland to promote the feeling of a self-contained campus. Like the "dogbone" buildings of Regent Park North, the towers were positioned at 45 degrees to the pre-existing street grid.

As was the case for many public housing developments realized in the ' 30 s and '40s, Regent Park was envisioned as way station for temporarily disadvantaged families. Given the anticipated brevity of the stay, the focus was on the quality of the unit (heat, running water, privacy) rather than on the provision of community infrastructure. Two-parent families with children were given priority as units came available. Social workers screened applicant families carefully to assure that those admitted had the best chance of success, i.e., would be most likely to move on in short order. Inevitably, however, the demographic of Regent Park changed over time. As policies increasingly privileged the most disadvantaged, the percentage of two-parent families dropped (as did the average household income) and the average length of stay increased substantially. In this context, the lack of community infrastructure in Regent Park became ever more problematic.

Crime rates climbed as the urban core deteriorated through the 1970s. The particularities of Regent Park's design proved propitious for criminal activity - most of which was attributable to individuals living outside the 
community. The lack of connection between individual units and the exterior meant that communal spaces were difficult to patrol; what was envisioned as a park became a collective no-man's land. Moreover, the absence of through streets made it difficult for police cruisers to patrol the neighborhood effectively. The designers' vision of Regent Park as an urban oasis proved problematic for an increasingly isolated and disenfranchised community.

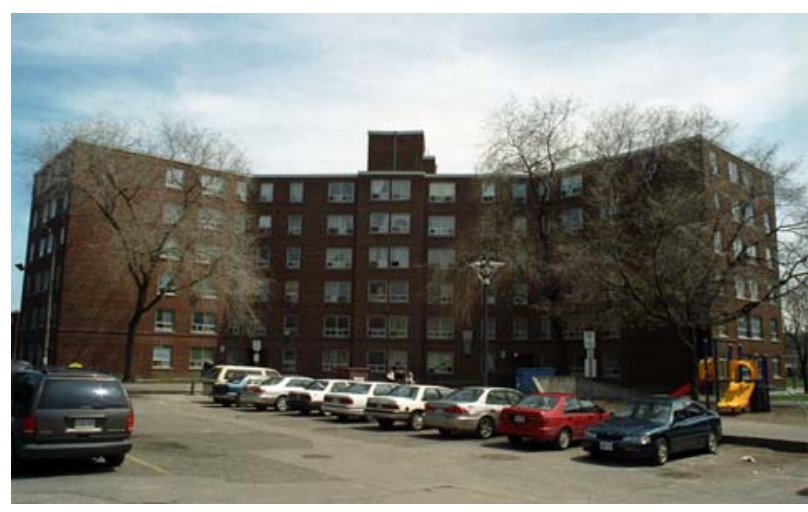

Figure 3: Regent Park North, 6-story "dogbone" building, courtesy Toronto Community Housing Corporation

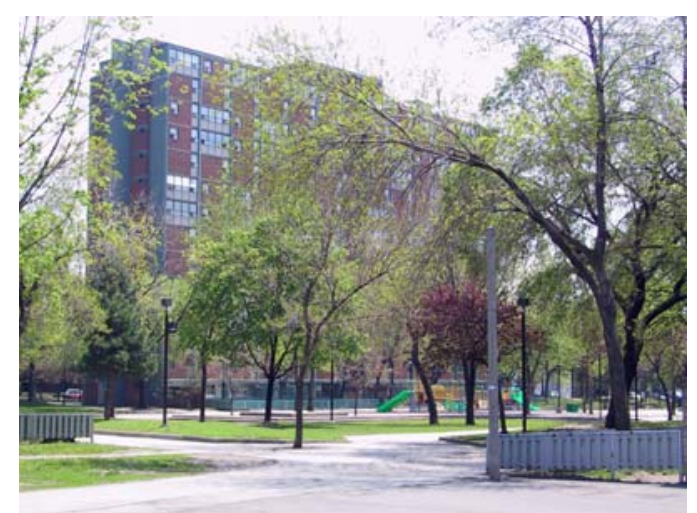

Figure 4: Regent Park South, "skip-stop" high-rise, courtesy Toronto Community Housing Corporation

Changes in the last several decades, however, have attracted segments of the middle class back to the city -particularly households without children. As of the mid 1970s the average cost of a house in the suburbs outpaced the average cost of a house citywide. As a result, first-time homebuyers began looking for alternatives. With advances in birth control and the choice to wait longer to have children, urban living re-emerged as a viable alternative. Supporting this trend, the introduction of the condominium designation made it possible both to live in the city and own one's dwelling.

The net effect of this is as follows: the cities in opposition to which housing projects like Regent Park were built no longer exist. Urban centers have transformed twice in the past fifty years. The city is neither the overcrowded and under-serviced environment it was at the end of WWII, nor is it the abandoned and deteriorating carapace it had become by the 1970 s (i.e., the city on which post-WWII suburbanization had taken its toll).

\subsection{Circumstances Leading to an Opportunity}

Unlike Europe where the focus was on rental housing, post WWII housing policy in North America encouraged home ownership. Mortgage programs promoted the purchase of small, detached, single-family homes, virtually all of which were produced by the private sector. The majority of the growth in the post-war period occurred on the periphery of large cities where land was abundant, inexpensive and increasingly accessible. Roughly $80 \%$ of the housing stock in Canada was built after WWII and the vast majority is suburban.

As the middle class migrated to newly built homes in the suburbs, the tax bases of most large cities dwindled. Diminished services (schools, etc.), in turn, exacerbated the drive to decamp. In reaction to the cumulative effects of suburbanization, governments supported the expropriation and large-scale redevelopment of the core. In some cases, e.g., Lafayette Park in Detroit, the goal was to encourage the middle class to return or remain in the city by providing viable alternatives to suburban homeownership. In most cases, however, urban renewal accommodated a shift from residential to commercial usages - augmenting the desirability and accessibility of the core as a place to work and/or engage in leisure activities. Redevelopment also presented the opportunity to adjust the traditional grain of the city. Smaller blocks were consolidated into superblocks to accommodate buildings with larger floor plates and to make way for new transportation corridors.

Poor and lower middle class neighborhoods (comprised of high percentages of renters) were razed to make way for new cultural, commercial, and transportation infrastructure. The housing of those displaced was the raison d'etre of many of the larger housing projects in the 1960s and '70s. Seen in its most positive light, urban redevelopment was envisioned as an opportunity for city to rebuild its tax base and offer displaced residents an improved standard of housing.

Whether they were built on (or adjacent to) the neighborhoods they replaced or in isolated corners of the city, these housing enclaves distinguished themselves from their surroundings. The design aspirations were inward, upward and away from adjacent neighborhoods. As was the case with Regent Park, many of these developments were cut off from city streets to discourage through-traffic. Planners envisioned protected green space over which children could roam freely; the effect, however, was ghettoization and stigmatization. 
More often than not, modernism was adopted for its economy, not for its design. Although it was certainly promoted on the basis of design principles -- light and air, lifting the tenant out of the dirty morass of the adjacent fabric, creating green lungs to enable the city to breathe - high-rise blocks were privileged for expediency and in service of open land (although the cost effectiveness of this can and has been argued). Given the decision to go vertical, many of the projects were built higher and/or at a greater density than originally designed.

Perhaps more importantly, the "tower in the park" model was often built without the park. Being the last thing to go in, landscaping was often the first thing to be sacrificed when facing (inevitable) cost overruns. Moreover landscaping requires ongoing maintenance and can present security risks. It is easier to bathe bare terrains in floodlight than to police parkscapes of hedges and mature trees. Even if resources were available to maintain it, tenants might be forced to choose between security and landscape amenities.

Perhaps most significantly, the demographic of the housing projects was more homogeneous than the neighborhoods they replaced. A variety of factors contributed to this including the lag between the demolition of the neighborhood and the availability of replacement housing. As selection processes increasingly favored the most severely disadvantaged, those who could afford to either choose or were forced to live elsewhere. Part of the problem was that the building of this housing was an externality, driven by non-residential redevelopment elsewhere in the core. In such cases housing was a means to a different end and could not command or sustain a significant amount of investment. While there is little question that many of the units demolished were substandard, what tenants gained in the quality of their units, they often lost in the quality of the community.

\subsection{The (sustainable) Redevelopment of the Redevelopment}

These notoriously conspicuous and conspicuously notorious projects have reached or are reaching their 40-year life cycle. A significant investment is required to upgrade them to current standards. As there is little support for rehabilitating what many consider to be failed social projects, housing authorities across North America are opting to demolish and replace them with market-driven housing. Over the past eight years, the US Department of Housing and Urban Development (HUD) has funded local housing authorities to demolish 60,000 units of public housing. HUD is also providing funds to replace these units and/or cause them to be replaced. To this end, local housing authorities are courting private sector partners with offers of free land, long-term lease guarantees, and tax incentives.

The decision to demolish is a function both of pragmatics and of ideology. It is arguably more cost effective to shift the responsibility for the construction, maintenance and operation of subsidized housing to the private sectori $^{\mathrm{vi}}$. But from an ideological perspective, the razing of housing estates is symptomatic of an acute and longstanding antipathy toward government-sponsored housing in North America. The dismantling of the most visible manifestations of public housing stock points to the fact that the combined political, social, and design ideologies underpinning these experiments have not proven sustainable.

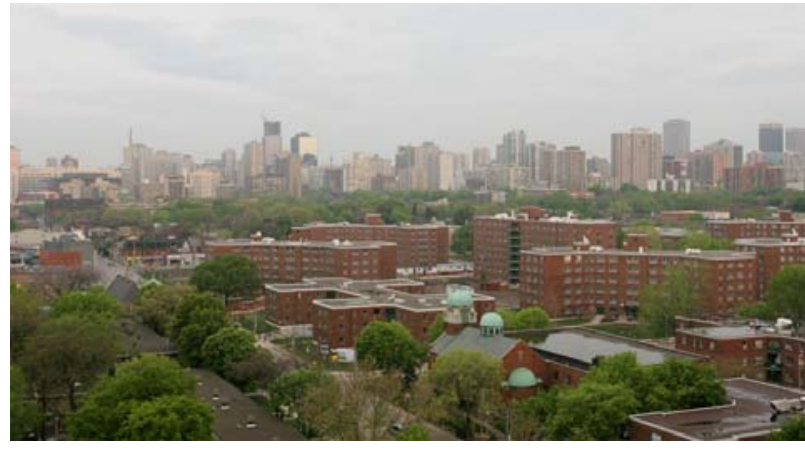

Figure 5: Regent Park Phase I redevelopment parcel, pre demolition, courtesy Toronto Community Housing Corporation (TCHC)

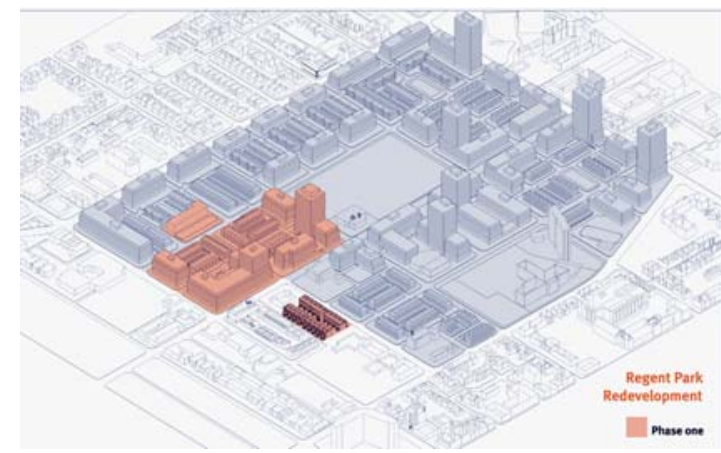

Figure 6: Proposed new construction, Phase 1, courtesy Toronto Community Housing Corporation

Where housing compounds are propitiously located in relation to desirable urban neighborhoods, the current real estate market presents its own incentives for redevelopment. Such is the case with Regent Park where Toronto Community Housing Corporation is brokering a $\$ 1$ billion redevelopment without the benefit of federal aid. While the form that the replacement housing takes varies with the project (in relation to its location and tenancy targets), subsidized units will be predominantly low rise vii. These units are designed to engage streets and, where possible, have separate entrances and street addresses. Where feasible, market-rate rental and condominium units are included the mix both to offset costs and to diversify and stabilize the neighborhoods. With respect to community design, an effort is being made to return to pre WWII urban patterns and to knit these neighborhoods 
back into the adjacent street fabric. The urban models once rejected in favor of modernist planning principles are now embraced as antidotes.

However much it might represent a failure of vision and design, the dismantling of the public housing stock presents an opportunity to apply sustainable design principles to large portions of the city in a coordinated way. Given that most large-scale housing projects were the result of urban renewal initiatives, their death and transfiguration provides another chance to engage in extensive renewal. Moreover the government's stake in these initiatives increases the chances that higher, more environmentally sustainable standards might be applied. That said, the presence of private investment means the short-term economics of these initiatives may drive what can and can't be done, i.e., that sustainability targets could be compromised in order to control costs and/or encourage private sector participation. As always, the question is who foots the bill, who receives the benefit, and how the benefit is defined and/or measured.

Within the context of this conference, sustainability is understood to mean a lessening of the negative impact of buildings (and by extension their inhabitants) on the environment. At issue are the design, construction and performance of buildings and communities throughout their life cycle. Engaging sustainability demands that we position buildings (and the activities they support) in a larger, temporal context. The way we define that context will determine the building materials we choose, the energy performance targets we set, the energy sources we exploit, the approaches taken to storm and waste water management, the amount, location and function of planting on the site, and the transportation alternatives offered to those who live and/or work in the community. A concerted and propitious approach to the choices made can mitigate the compound's environmental footprint and reduce the long-term costs. If the long-term costs are lower, the buildings have a greater chance of surviving.

Given its extremely favorable location within the urban core, Regent Park is poised to make significant advances both with respect to current conditions on the site and to other sectors of the city. Sustainability targets for the redevelopment have been set as follows ${ }^{\text {viii. }}$

- $\quad 35 \%$ reduction in water use per capita

- $20 \%$ reduction in storm water runoff

- $84 \%$ removal of solids in storm water

- $35 \%-60 \%$ solid waste diversion rates in all buildings

- $\quad 90 \%$ diversion of demolition and construction waste diversion

- $\quad$ reduced environmental impact in building products

- improved modal split and support for nonauto transportation

- improved natural environment and water use through low maintenance landscape strategies

- up to $50 \%$ below code for energy consumption

- reduction of up to $70 \%$ in green house gas emissions

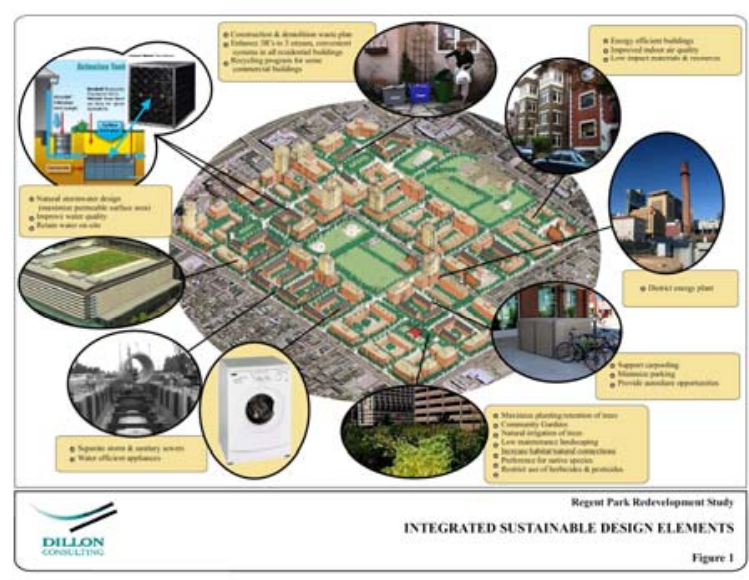

Figure 7: Regent Park Sustainability Targets, courtesy Dillon Consulting

A central energy plant will service the entire 69-acre development, permitting significant economies of scale and decreasing dependence on the grid. A gas-fired generator will produce electricity for the community, heat from which will be captured and distributed using a hot water system. Both heating and cooling will be provided centrally with geothermal backup. ${ }^{\mathrm{ix}}$

Given these aggressive targets, it is significant to note that Regent Park will be redeveloped at more than double its current density. Accommodating more residents within the urban core will alleviate pressure on exurban expansion, leverage municipal services more efficiently, and reduce the number of commuters on the Toronto's overcrowded freeways. Figures are as follows:

Built density:

- Current: 0.75

- Proposed: gross density of 2.1 -- 585,000 sq. m. of gross floor area (net density, subtracting streets and parks, will be 2.8)

- Delta: x 2.8 (planned density will about triple the current density) 


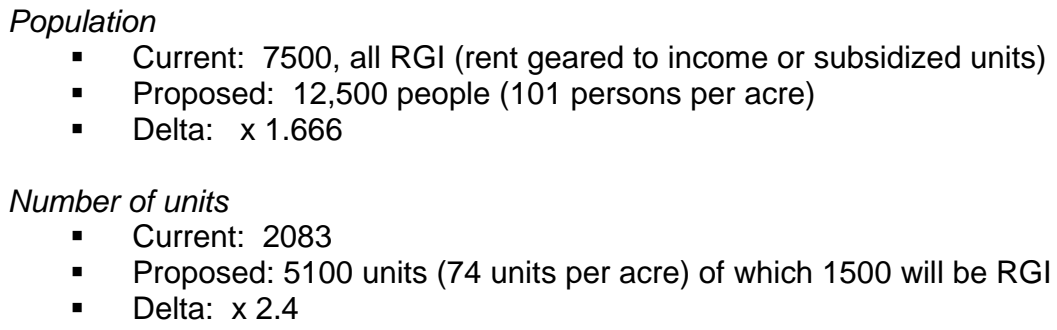

\subsection{Stepping Back to Move Forward}

Costs (long- and short-term, financial and environmental), however, are not the only factor. Indeed, the most compelling aspect of the current chapter in the history of public housing is what it tells us about the limits of sustainability within a larger social, political and historical context. The fact that 1) virtually no public housing has been built in North America for the past 30 years, and that 2) the bulk of the public housing stock is not likely to survive its 40-year life cycle, suggests the degree to which the undertaking was not sustainable. But doing nothing -- allowing neighborhoods to deteriorate and ignoring the forces at play in the urban core during an era of mass suburbanization -- would have been neither a prudent nor sustainable alternative.

In considering the rise and fall of public housing it is helpful to distinguish between related considerations, namely

- $\quad$ that public housing was built (a necessary evil, an unpopular undertaking, doomed from the start)

- $\quad$ compared/opposed to what was intended (design issues/ideology, social vision)

- $\quad$ compared/opposed to the way it was realized (where it was built, what components of the design were actually realized, the level of funding, the quality of the construction, the terms of reference, etc.)

- $\quad$ compared/opposed to how and by whom it was inhabited, related to how and by whom it was administered

- $\quad$ compared/opposed to the cost of doing nothing (assuming this was even an alternative).

Among the issues at play, then, when considering where we go next are (in no particular order):

- Sustainability as a design consideration, both at the scale of the building and of the community.

- The sustainability of the idea of public housing in North America in relation to the form it takes. The form affects the level of political support, which, in turn, determines the long-term success of the undertaking. In this context form can mean architectural form (e.g., high rise or low rise, apartment or townhouse) and/or urban form (e.g., high density or low density, ratio of public to private spaces/amenities, degree of connection to or isolation from adjacent fabric). Arguably the fact that public housing takes form at all is at issue; experience suggests that subsidized housing survives best when it is invisible and/or indistinguishable from the housing stock at large.

- The role that environmental sustainability might play in engendering support for investment in model, mixed demographic communities -- among or within which may be aggregations of government-sponsored housing.

- $\quad$ The government's role in any urban initiative, and the terms of reference by which it can or should participate/intervene, especially when it is contributing financially or by legislative fiat.

- Sustainability as a function of the demographic mix of a community - as expressed in the ratio of subsidized to market-rate units and of owner-occupied to rental units. Our experience with public housing in the $20^{\text {th }}$ century strongly suggests that homogeneity is sustainable only in relation to wealth. In this respect, it is less the form (urban or architectural) that public housing takes that is at issue (indeed high rise complexes are a viable alternative for many sectors of the population), but its form in relation to the demographic it is expected to accommodate.

- The urban context as a milieu in which economic and demographic forces are constantly at play. This affects the ability of any building or complex of buildings - particularly housing -- to survive. Arguably the failure of public housing relates not only to the demographic that inhabits it, but also to the fact that it rarely accommodates the demographic for which it was designed. Housing and communities must be designed to support change in order to survive it.

- $\quad$ Given that the terms, conditions and technologies surrounding sustainability continuously transform, we might question whether any building should survive its 40-year life cycle. Which buildings (should and/or do) survive and why? As noted above, the ability to adapt is one of the key criteria in evaluating the long-term 
sustainability of a building or complex. Sadly neither design excellence nor an extremely high quality of construction can save a building that, for whatever reason, finds itself in the wrong place at the wrong time.

\section{CONCLUSION}

What we're witnessing with respect to the public housing stock in the US and Canada is a double erasure. Traditional mixed-use neighborhoods like Cabbagetown were razed to make way for the housing that is now being cleared to make way for (neo) traditional mixed-use neighborhoods. As such, it is important to consider how these events reflect on the concept of sustainability as it applies to the city. Indeed the urban renewal efforts of the 1960s and '70s were predicated on the fact that the city had proven unsustainable and that massive interventions were required to shore it up. Moreover reformers had argued for alternative forms of urbanity for more than a century before urban renewal initiatives were finally undertaken. The fact that modernist housing compounds are now being replaced with the very fabric they once supplanted reminds us that what is not sustainable in one era may emerge as the most sustainable alternative in another.

Implicit in these observations is the suggestion that portions of our modernist public housing stock should be preserved, rehabilitated and directed toward a different demographic. Indeed, the same strategies that Yamasaki applied to the design of Pruit-Igoe (public housing) appear in his proposals for Lafayette Park (middleclass housing). Moreover had erasure proven effective as a strategy it is unlikely we would be considering the same strategy for the same sites in such short order.

That said, our public housing stock has several strikes against it:

- $\quad$ Depression-era projects were required to be built of an equal or lesser quality than adjacent, privately owned rental housing lest they compete with (and further disadvantage) private landlords. More often than not, the adjacent housing stock was of questionable quality.

- Most of these projects were built without community infrastructure, lest they encourage (implicitly or explicitly) tenants to stay.

- $\quad$ More often than not, the public housing stock has been subject to changing demographics, meaning that complexes rarely accommodate the constituencies for whom they were designed. The effect has been to put the buildings under extraordinary stress. Arguably, the lower the income of the tenant, the more stress a unit is subjected to.

- Enmity toward the poor, racial discrimination, and a deeply ingrained anti-urban sentiment translated to a profound lack of support for much of what was built - meaning it was built with as little money possible and in the least desirable locations. In other words, it was not designed to last. Arguably this is consistent with the idea that public housing should serve as a temporary way station for temporarily disadvantaged families. As real solutions to poverty and housing were seen to lie elsewhere, investing in public housing was seen as treating the symptom, not the problem.

- Housing complexes often accompanied or were the result of adjacent infrastructure projects (e.g., interstates) that cut them off from the surrounding city. This isolation exacerbated their decline.

Thus where cities are concerned, principles of sustainability must take account of the concept of change in its myriad manifestations. Among these is the cyclical phenomenon of death and transfiguration. The opportunity to apply a sustainability-informed agenda to the redevelopment of public housing complexes represents an opportunity to re-write the ending to a story whose plot has been ambiguous at best. In both its previous (post WWII) and imminent incarnations, Regent Park has been a laboratory for the best minds and most worthy aspirations of our era. As a model sustainable community (assuming it manages to realize the goals it has set), Regent Park's transfiguration will be tantamount to redemption.

\footnotetext{
${ }^{\mathrm{i}}$ Funding is provided under the Hope VI program.

ii The Chicago Housing Authority alone will demolish 12,000 units across 31 different projects. These include the high-rise structures such as the Robert Taylor Houses on Chicago's South Side as well as the 4-story Ida Wells and Jane Addams Houses built during the Depression.

iii Both Canada and the US have exceeded their ownership targets; approximately 66\% of households own homes.

iv This program is known generally as Section 8 in the US.

$v$ "Statement by Mayor Robert H. Saunders in Connection with Regent Park Low-Cost Housing Project" (Toronto, December 1946), pg. 1, as cited in Rose, Albert, Regent Park: a Study in Slum Clearance, 1958, University of Toronto Press, pg. 64

${ }^{v i}$ Much of the rental housing built by government authorities in Europe is also being sold off to the private sector.

vii See description of housing being planned by the Chicago Housing Authority on the site of the former Robert Taylor houses, CHA web site.

viii Source, Toronto Community Housing Corporation, November 2006.

${ }^{i x}$ Another excellent example of a social housing rehabilitation that led to some significant sustainability results is the Benny Farm project in Montreal. See www.bennyfarm.org
} 